\title{
The Improvement of Fault Recovery with RES Penetration
}

\author{
N.Ravi, Y.Sumanth, N.Dharani Kumar \\ I. (M.Tech (PS)) EEE Department, RVR \&JC College of Engineering, Guntur, INDIA. \\ 2,3, Asst.Professor, Dept of EEE, R.V.R. \&J.C. College of Engineering, Guntur, INDIA.
}

\begin{abstract}
Recently, several types of Distributed Generators (DGs) have been connected together to form a small power normal connecting mode and is connected to the main grid. This paper presents the performance enhancement of microgrid with RES (Renewable Energy Sources) penetration in grid connected and islanded operation, and also shows the effect of wind and solar penetration individually and as well as coupled along with backup protection. To analyze the effect of RES penetration into micro grid a synchronous speed wind turbine equipped with SCIG (Squirrel cage Induction Generator) and solar system with MPPT (Maximum Power Point Tracking) are used. A modified Benchmark micro grid is used and simulations are performed in the MATLAB/SIMULINK environment.
\end{abstract}

Index Terms: Micro grid, renewable energy sources, Reactive power mismatching, solar integration, voltage stability, wind penetration, battery.

\section{Introduction}

Power system is the one which consist of all the electrical equipment's (i.e. generator, transmission line, transformer, and etc.) which are placed at different places depend upon the requirement they are working together in order to supply the electrical energy to the consumers. Load demands are continuously increasing day by day for which the transmission lines are getting more loaded. As load increases stability is affected by the loading effect of transmission line after small disturbance. To minimize the loading effect of transmission line, the recent trend of distribution network service providers is to introduce significant generation at distribution level which is often called distributed generation (DG). DG changes the power flow within the network, i.e., integration of DG causes bi-directional power flow, which reduces the capacity of feeder and transmission line. The other benefits of distributed generation include the reduction of power loss, better voltage support, peak shaving, and the improvement of overall efficiency, stability and reliability. Micro grid is an important auxiliary part of the distribution. Micro grid consists of some micro sources and loads and can operate in both islanded and grid connected mode along with backup protection.

Renewable energy sources: - RES is defined as energy that comes from resources which are naturally replenished on a human time scale such as Wind, sunlight, rain, tides, wave and etc., here RES is used as distributed generation in Microgrid.

\section{Types of Renewable Energy Sources:}

Solar Power: Solar renewable energy, also known as photovoltaic renewable energy, harnesses the power of the sun to produce electricity. Solar cells convert the sun's energy into electricity through semiconductors. Although a complicated technology, solar PV can be deployed in compact panels, turning roofs into the perfect energygenerating platform. The photovoltaic process involves the movement and displacement of electrons to absorb the sun's radiation and create electricity, but there are also solar systems that use large scale mirrors to heat water, or produce high temperatures and generate steam, which is used to turn a generator. Wind Power: Another alternative to produce electricity is wind energy supplied by the wind. The device able to perform this conversion is called wind generator, this consists of a mechanical system of rotation which is powered by blades as in old windmills. This rotary system is connected to an electric generator whose axis joined to the driving system. In this way the wind, forcing the blades to turn, drives the electric generator which can be either a dynamo or an alternator (the alternator, in comparison to the dynamo, presents the advantage of a higher efficiency, supplying energy at a lower speed, and supplying more energy at higher speed). Wind is unique because it carries incentives for farmers to give parcels of land for building wind turbines, and has the most potential as far as widespread adoption due to the large areas of land with consistent wind available to harness. Advantages of RES:-It is renewable require less Maintenance. Products such as carbon dioxide and chemical products so has minimal impact on the environment. Disadvantages of RES: It is difficult to generate the quantities of electricity that are as large as those produces by traditional fossil fuel generators. Renewable energy often relies on the weather for its source of power. Hydro generators need rain to fill dam to supply 
flowing water. Wind turbine needs wind to turn the blades. Solar collectors need clear skies and sunshine to collect heat and make electricity

\section{Distributed Generation:}

Distributed generation (DG) generally refers to small-scale electric power generators that produce electricity around $(1 \mathrm{KW}-50 \mathrm{MW})$ at a site close to customers or that are tied to an electric distribution system. Distributed generators include synchronous generators, induction generators, micro turbines combustion gas turbines, fuel cells, solar, photovoltaic, and wind turbines.

Benefits of Distributed Generating Systems: It has a lower capital cost because of the small size of the DG (although the investment cost per kVA of a DG can be much higher than that of a large power plant).It May reduce the need for large infrastructure construction or upgrades because the DG can be constructed at the load location. If the DG provides power for local use, it may reduce pressure on distribution and transmission lines. With some technologies, produces zero or near-zero pollutant emissions over its useful life (not taking into consideration pollutant emissions over the entire product lifecycle i.e. pollution produced during the manufacturing or after decommissioning of the DG system). With some technologies such as solar or wind, it is a form of renewable energy. Can increase power reliability as back-up or stand-by power to customers

Microgrid :- A group of interconnected loads and distributed energy resources with clearly defined electrical boundaries that acts as a single controllable entity with respect to the grid connect and disconnect from the grid to enable it to operate in both grid connected or islanded mode. Micro grid is an importance part of the distribution system. Advantages: Efficiency, Reliability, Energy security, Economic savings, sustainability.

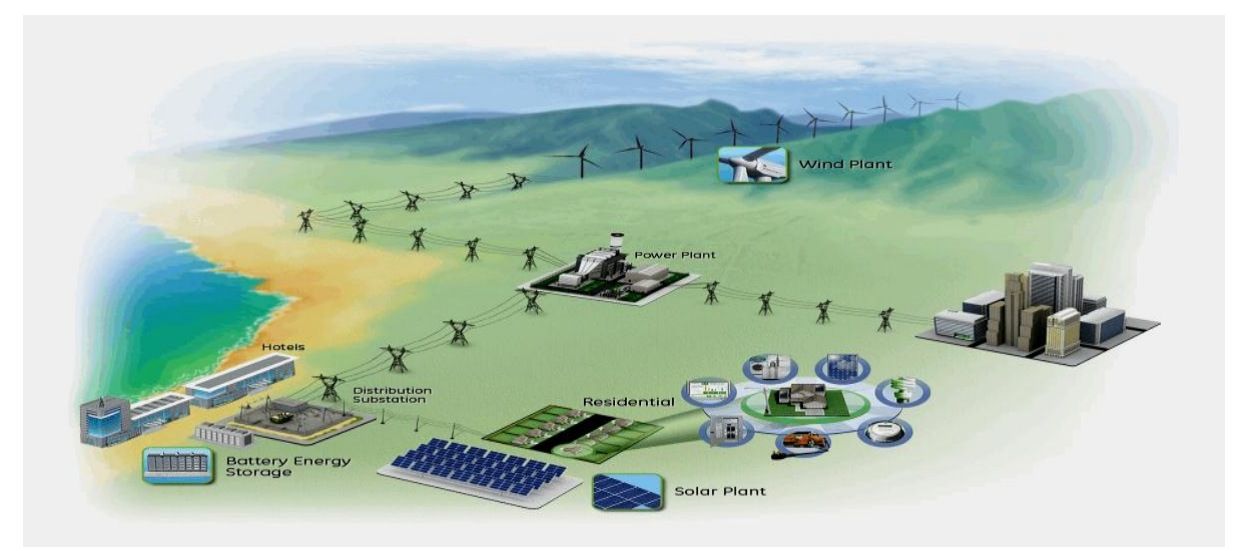

Fig. 1.Microgrid Electricity System

\section{Test System}

A modified bench mark micro grid test system is shown in fig. 1 which is used in this simulation. There are four different zones. In zone 1, hydroelectric and solar power is available which is defined by DG1. Only solar power is available in zone 2 and zone 3 which is defined by DG2 and DG3. DG4 includes wind and solar power generation. The average total load of this micro grid is 9 MVA including an induction motor of rating 2 MVA connected at node 3 .

Micro grid is connected to a supply via grid $69 / 13.8 \mathrm{KV}$ substation. In Islanded mode, total load is supplied by distributed generation, Here wind, solar, hydroelectric is used as the base power generation. In Islanded mode, total load is supplied by distributed generation, Here wind, solar, is used as the base power generation. Micro grid is the part of distribution system but characteristics of Micro grid in islanded mode is different from distribution system. A fixed speed wind turbine is equipped with SCIG (Squirrel cage induction generator) to generate electrical power. Photovoltaic cell is equipped with MPPT and is connected to grid via an inverter. In this system, battery storage is arranged due to whenever power demand is more in that situation any one of the wind turbine or solar PV cells are failed to supply the energy at that instant required energy is obtained from battery backup storage.

\section{Modeling of the Generators}

A. Wind generator: - It is the conversion of wind energy into a useful form of energy. Due to availability of wind universally wind energy generation is increasing day to day which helps to develop rural electrification, create job opportunities and having the ability to harness the power available in the wind \& put it into useful work. Wind speed forecasting has high uncertainty, high volatility and low predictability, which reduces the system security and wind revenue and major problem of wind penetration is to maintain voltage profile. Wind turbine is coupled with SCIG (Squirrel cage Induction Generator). 
An SCIG is coupled with wind turbine to convert wind energy to electrical power. A standard SCIG model is used in MATLAB/SIMULINK and wind turbine is equipped with wind source and wind governor. Wind governor controls the pitch angle of the wind turbine considering the output power of the turbine and wind speed. Output power of the wind turbine can be expressed as (1) [39].

$$
\mathrm{P}_{\mathrm{out}}=\frac{1}{2 \cdot 10^{6}} \rho \cdot \mathrm{A} \cdot \mathrm{C}_{\mathrm{p}} \cdot \mathrm{V}^{3} \cdot \eta_{\mathrm{gb}}
$$

where, $\rho$ is the density of air, $\mathrm{A}$ is the swept area of the blade, $\mathrm{V}$ is the wind velocity, $\eta_{\mathrm{gb}}$ is the efficiency of gear box and $\mathrm{Cp}$ is the power coefficient which depends on tip speed ratio $\lambda$ and pitch angle $\beta . \mathrm{C}_{\mathrm{p}}$ is given by the following relation:

$$
\mathrm{C}_{\mathrm{p}}=\frac{1}{2}\left(\lambda-5.6-\frac{\beta}{45}\right) \mathrm{e}^{-\frac{\lambda}{6}}----(2)
$$

In a wind turbine, wind blade is connected to low speed shaft. Wind power is transferred from low speed shaft to rotor (high speed shaft) of the generator via a gearbox. The dynamics of the shafts and gearbox can be expressed by the equations (3)-(5) [7].

$$
\begin{aligned}
& \dot{\omega}_{\mathrm{l}}=\frac{1}{2 \mathrm{H}_{\mathrm{l}}}\left(\mathrm{T}_{\mathrm{ae}}-\mathrm{T}_{\mathrm{m}}-\mathrm{D}_{\mathrm{l}} \omega_{\mathrm{ml}}\right) \\
& \dot{\omega}_{\mathrm{h}}=\frac{1}{2 \mathrm{H}_{\mathrm{h}}}\left(\mathrm{T}_{\mathrm{m}}-\mathrm{T}_{\mathrm{e}}-\mathrm{D}_{\mathrm{h}} \omega_{\mathrm{h}}\right) \\
& \dot{\lambda}=2 \pi \mathrm{f}\left(\omega_{\mathrm{l}}-\frac{1}{\mathrm{~N}_{\mathrm{g}}} \omega_{\mathrm{h}}\right)
\end{aligned}
$$

where, $\omega_{l}$ and $\omega_{h}$ are the speed, $\mathrm{H}_{1}$ and $\mathrm{H}_{\mathrm{h}}$ are the inertia constant and $\mathrm{D}_{\mathrm{l}}$ and $\mathrm{D}_{\mathrm{h}}$ are the torsion damping of the low and high speed shaft respectively. $\mathrm{T}_{\mathrm{ae}}, \mathrm{T}_{\mathrm{m}}$ and $\mathrm{T}_{\mathrm{e}}$ are the aerodynamic, mechanical and electrical torque respectively and $\mathrm{N}_{\mathrm{g}}$ is the gearbox ratio.

B. Grid connected PV system: Photovoltaic panels convert the sunlight directly into electricity. A typical example of a device powered by photovoltaic cells is a solar powered calculator. This type of device only needs a small amount of electrical power to work and even can be used in a room with artificial light (bulbs / fluorescent light). Photovoltaic cells have been developed to provide electrical power to pump drinking water from wells in remote villages. British Telecom has developed a system that can be used to power a radio telephone system. During the day the cells power the phone and also charge batteries. The batteries power the phone during the night. Often photovoltaic cells are used as a backup to conventional energy. If conventional fails the cells are used to produce electricity.

\section{Typical Photovoltaic Cells:}

Silicon is a material known as a 'semiconductor' as it conducts electricity and it is the main material for photovoltaic cells. Impurities such as boron phosphorous are added to this base material. These impurities create the environment for electrons to be freed when sunlight hits the photovoltaic panel. The freeing of electrons leads to the production of electricity.

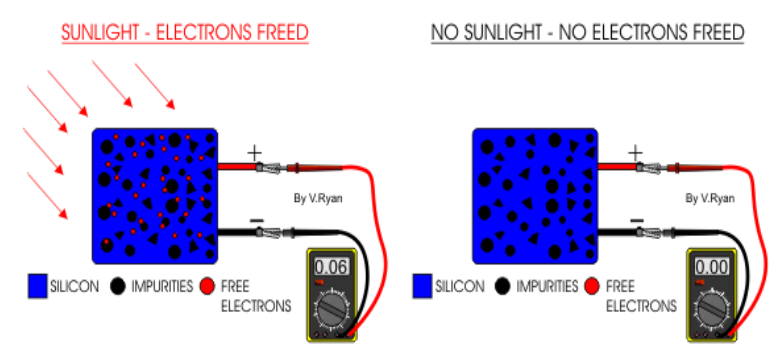

Fig. 2: Basic photovoltaic cell

The diagram above shows a basic photovoltaic cell. The blue represents the main material silicon. The black round and irregular shapes represent the impurities of boron or phosphorous. As the sun light strikes the cell the impurities free up electrons which 'bounce' around at incredible speeds. This creates an electrical charge. 


\section{Modeling a PV Cell:}

The use of equivalent electric circuits makes it possible to model characteristics of a PV cell. The method used here is implemented in MATLAB programs for simulations. The same modeling technique is also applicable for modeling a PV module. The simplest model of a PV cell is shown as an equivalent circuit below that consists of an ideal current source in parallel with an ideal diode. The current source represents the current generated by photons (often denoted as $\mathrm{I}_{\text {poh }}$ or $I_{L}$ ), and its output is constant under constant temperature and constant incident radiation of light.

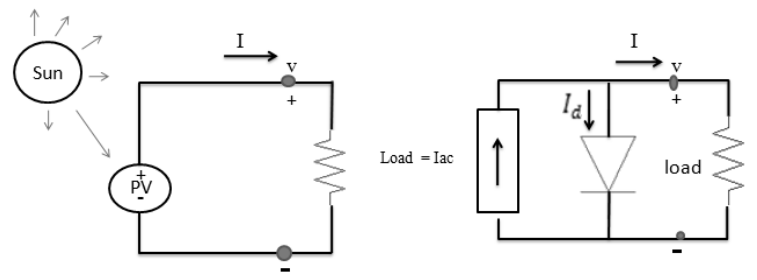

Fig.3 (a): PV cell with a load and its simple equivalent circuit.

There are two key parameters frequently used to characterize a PV cell. Shorting together the terminals of the cell, as shown in Fig. 3 (a), the photon generated current will flow out of the cell as a short-circuit current $\left(S_{\mathrm{ic}}\right)$. Thus, $\mathrm{I}_{\mathrm{poh}}=\mathrm{S}_{\mathrm{ic}}$. As shown in Fig. 3 (b), when there is no connection to the PV cell (open-circuit), the photon generated current is shunted internally by the intrinsic p-n junction diode. This gives the open circuit voltage (Voc). The PV module or cell manufacturers usually provide the values of these parameters in their data sheets.

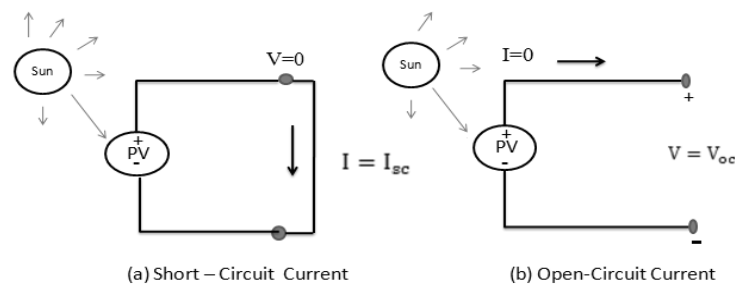

Fig.3 (b): Diagrams showing a short-circuit and an open-circuit condition

The output current (I) from the PV cell is found by applying the Kirchhoff's current law (KCL) on the equivalent circuit shown in Figure.

$$
\mathrm{I}=\mathrm{I}_{\mathrm{sc}}-\mathrm{I}_{\mathrm{d}}---(6)
$$

Where: $I_{s c}$ is the short-circuit current that is equal to the photon generated current, and $I_{d}$ is the current shunted through the intrinsic diode. The diode current $\mathrm{I}_{\mathrm{d}}$ is given by the Shockley's diode equation.

$$
I_{d}=I_{o}\left(e^{\frac{\mathrm{qV}_{d}}{k T}}-1\right)---(7)
$$

equation (6) by the equation (7) gives the current-voltage relationship of the PV cell.

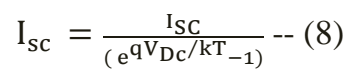

Where: $V$ is the voltage across the PV cell, and I is the output current from the cell. The reverse saturation current of diode $\left(\mathrm{I}_{\mathrm{o}}\right)$ is constant under the constant temperature and found by setting the open-circuit condition as shown in Fig. 4. Using the equation (8), let $\mathrm{I}=0$ (no output current) and solve for $I o$.

$$
\begin{gathered}
0=\mathrm{I}_{\mathrm{sc}}-\mathrm{I}_{\mathrm{o}}\left(\mathrm{e}^{\mathrm{qV} / \mathrm{kT}}-1\right)--(9) \\
\mathrm{I}_{\mathrm{sc}}=\mathrm{I}_{\mathrm{o}}\left(\mathrm{e}^{\mathrm{qV_{ \textrm {Dc } } / \mathrm { kT }}}-1\right)--(10) \\
\mathrm{I}_{\mathrm{o}}=\frac{\mathrm{I}_{\mathrm{sc}}}{\left(\mathrm{e}^{\mathrm{qV} \mathrm{Dc}_{\mathrm{Dc}} / \mathrm{kT}}-1\right)}--(11)
\end{gathered}
$$

To a very good approximation, the photon generated current, which is equal to $\mathrm{I}_{\mathrm{sc}}$, is directly proportional to the irradiance, the intensity of illumination, to PV cell [15]. Thus, if the value, $\mathrm{I}_{\mathrm{sc}}$, is known from the datasheet, under the standard test condition, $\mathrm{G}_{0}=1000 \mathrm{~W} / \mathrm{m}^{2}$ at the air mass $(\mathrm{AM})=1.5$, then the photon generated current at any other irradiance, $\mathrm{G}\left(\mathrm{W} / \mathrm{m}^{2}\right)$, is given by: 


$$
\mathrm{I}_{\mathrm{sc}} \mathrm{I}_{\mathrm{G}}=\left(\frac{\mathrm{G}}{\mathrm{G}_{\mathrm{o}}}\right) \mathrm{I}_{\mathrm{sc}} \mathrm{I}_{\mathrm{G}}
$$

Fig.5. shows that current and voltage relationship (often called as an I-V curve) of an ideal PV cell simulated by MATLAB using the simplest equivalent circuit model. The discussion of MATLAB simulations will appear in Section III. The PV cell output is both limited by the cell current and the cell voltage, and it can only produce a power with any combinations of current and voltage on the I-V curve. It also shows that the cell current is proportional to the irradiance.

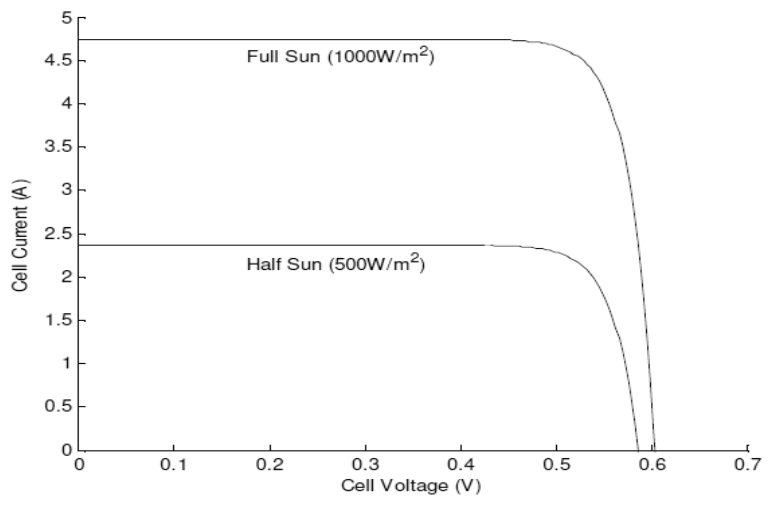

Fig.4. I-V plot of ideal PV cell under two different levels of irradiance $\left(25^{\circ} \mathrm{C}\right)$.

\section{Constraints of solar panels:}

High installation cost, Low generation capacity, Uncertainty of solar irradiance, power fluctuations due to intermittency behavior of sunlight. Solar penetration changes the voltage profile and frequency response of the system, photovoltaic system are maintained at unity power factor and the characteristics of the solar panel depend upon the inverters. Photovoltaic system has no inertia; some extra devices are required to maintain frequency oscillation.

A solar cell can be expressed as a DC current source with a series resistance, a parallel resistance and a parallel diode. A grid connected photovoltaic system is shown in Fig.2. Solar cell output current $\left(\mathrm{I}_{\mathrm{vy}}\right)$ can be expressed by the equation (6) [40].

$$
\begin{gathered}
\mathrm{I}_{\mathrm{pv}}=\mathrm{I}_{\mathrm{ph}}-\mathrm{I}_{\mathrm{o}}\left[\mathrm{e}^{\left[\frac{\mathrm{V}_{\mathrm{dc}}+\mathrm{I}_{\mathrm{pvR}}}{\mathrm{nKT} / \mathrm{q}}\right]}-1\right]-\frac{\mathrm{V}_{\mathrm{dc}}+\mathrm{I}_{\mathrm{pv}} \mathrm{R}_{\mathrm{s}}}{\mathrm{R}_{\mathrm{sh}}}- \\
I_{p h}=I_{s c} \frac{G}{G_{r}}\left[1+\alpha_{T}\left(T-T_{r}\right)\right]---(14) \\
I_{o}=I_{r}\left(\frac{T}{T_{r}}\right)^{3} e \frac{q E_{q}}{n K}\left(\frac{1}{T_{r}}-\frac{1}{T}\right)---(15)
\end{gathered}
$$

Where, $I_{s c}$ and $I_{r}$ are the short circuit current of solar collector at the reference temperature and dark current at reference temperature respectively, $G_{r}$ and $T_{r}$ are the reference radiation and temperature respectively. Dynamics of this system can be presented (in do frame) by equations (16)-(18) [41].

$$
\begin{gathered}
\dot{i_{d}}=\frac{R}{L} i_{d}+\omega i_{q}+K_{d} \frac{V_{d c}}{L}-\frac{E_{d}}{L}----(16) \\
\dot{i_{q}}=-\frac{R}{L} i_{q}-\omega i_{d}+K_{q} \frac{V_{d c}}{L}-\frac{E_{q}}{L}---(17) \\
\dot{V_{d c}}=\frac{1}{C V_{d c}}\left(P_{p v}-P_{o}\right)---(18)
\end{gathered}
$$

Where, $\mathrm{P}_{\mathrm{pv}}$ and $\mathrm{P}_{\mathrm{o}}$ are the solar power and output power to the grid respectively. $\mathrm{E}_{\mathrm{d}}, \mathrm{E}_{\mathrm{q}}, \mathrm{i}_{\mathrm{d}}$ and $\mathrm{i}_{\mathrm{s}}$ are the direct and quadratic axis voltages and currents respectively. The other parameters appearing in equations (9)(18) are the series resistance $\left(\mathrm{R}_{\mathrm{s}}\right)$, parallel resistance $\left(\mathrm{R}_{\mathrm{ash}}\right)$, DC link voltage $\left(\mathrm{V}_{\mathrm{ic}}\right)$, resistance $(\mathrm{R})$ and inductance (L) of connected line to grid, electron charge(q), band-gap energy of the solar cell material $\left(\mathrm{E}_{\mathrm{gg}}\right)$, Boltzmann constant $(K)$, diode ideality factor $(n)$, temperature coefficient $\left(a_{t}\right)$, controller signal of inverter in d-axis $\left(K_{i d}\right)$ and $\mathrm{q}-\operatorname{axis}\left(\mathrm{C}_{\mathrm{hq}}\right)$ and angular velocity $(\omega)$. 


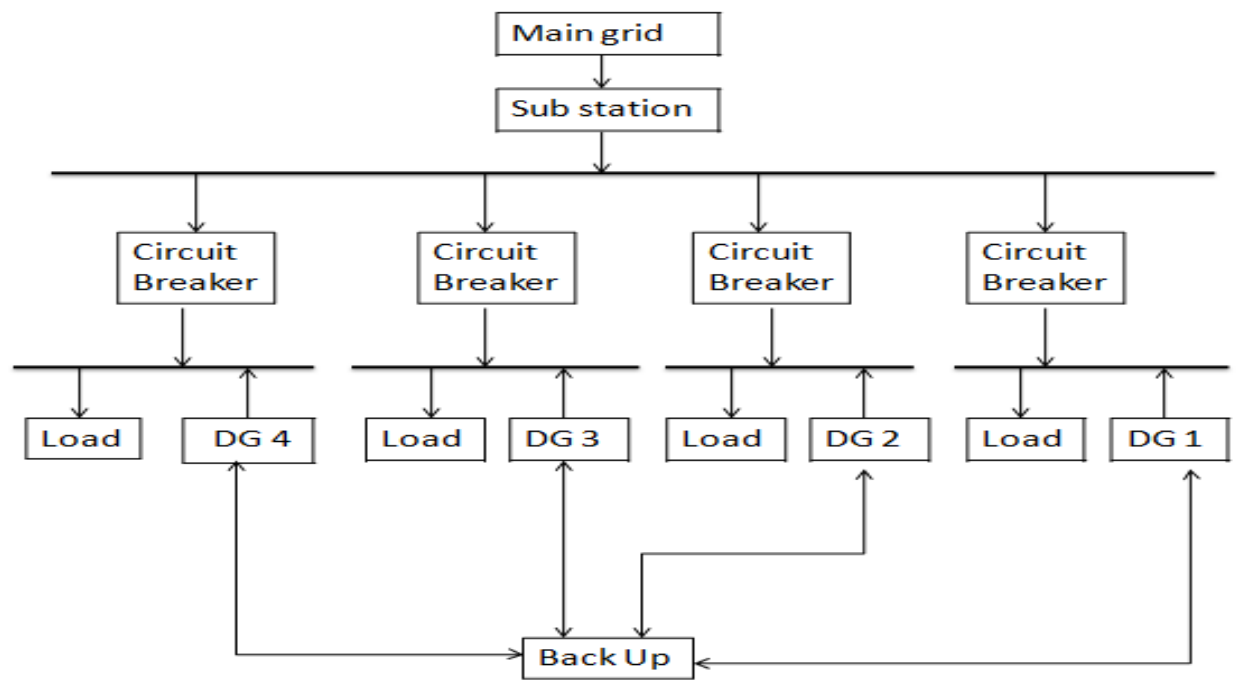

Fig. 5: A Modified Benchmark Micro grid test system.

The Effect of the Wind and Solar Penetration is analyzed for Distribution system Micro grid is the part of the distribution system. Microgrid is defined as an integrated energy system intelligently managing interconnected loads and distributed energy resources and capable of operating in parallel with, or independently, from the existing utility's grid.

\section{Simulation Results}

Main intension of the paper is to study the effect of RES penetration on voltage stability at the time of connecting and disconnecting wind, solar or both with RES system. The simulation result shows the impact on the system voltage of RES Penetration in Micro Grid and difference in effect between distribution system and micro grid. To analyze the impact of RES penetration, the system in above block diagram is simulated for $10 \mathrm{~s}$. In all simulations, at time $t=0 \mathrm{~s}$ all feeders and loads are connected. Initially micro grid is connected to the main grid and all power demand is supplied by the main grid, i.e., all DG's are disconnected. RES's are connected to micro grid at $1 \mathrm{~s}$ and disconnected from grid at $3 \mathrm{~s}$.

\section{Effect of Wind Penetration:}

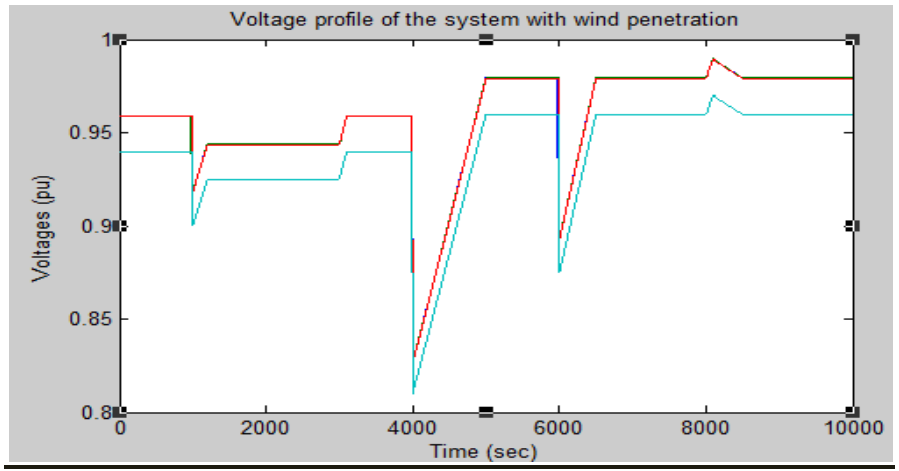

Fig.6: Voltage profile of the system with wind penetration.

In this section wind penetration effect on voltage stability is presented for different situations and also the difference between grid connected and islanded mode. A $2 \mathrm{MW}$ wind generator has been connected at node 4 and the voltages at the various nodes as shown above. From the figure the penetration of wind not only affects the point of connection but also entire system. At the time of connecting wind generation to grid, voltages of all nodes fall down. In microgrid $23 \%$ wind penetration causes voltage variation around $1 \%$ in grid connected mode and less in islanded mode. Voltage variation is less in islanded mode this is due to short distance of synchronous generator from wind generator which supplies the reactive power requirement of wind generator in islanded mode. 


\section{Effect of Solar Penetration :}

Generation size of solar cell is small. A PV system supplies the real power to the system and does not consume any reactive power. Voltage of the system changes due to increase in generation as shown below. Voltages at all nodes increase with solar integration. Also fluctuation at the transient moment is higher in islanded mode due to lower inertia of the system.

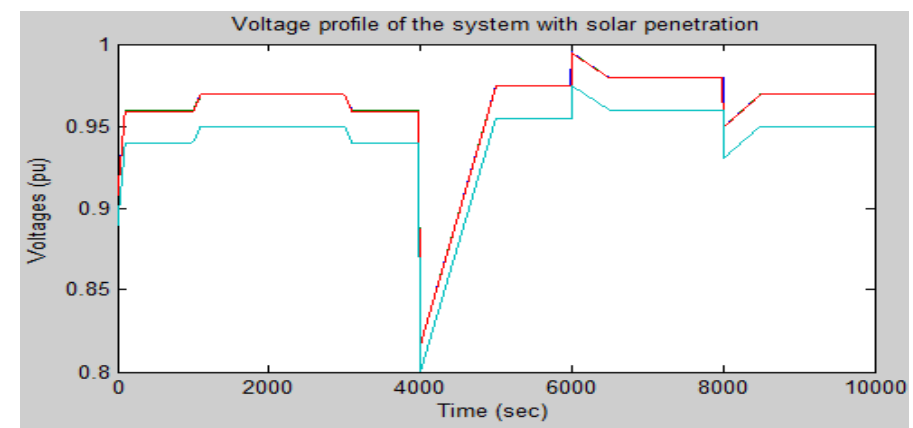

Fig.7: Voltage profile of the system with solar penetration.

\section{Combined effect of wind and solar penetration :}

Combined effect of wind and penetration with comparing wind and solar itself is shown above. Wind penetration causes drop due to reactive power consumption and solar penetration increases the voltages due to real power injection into the grid. Also solar system can supply reactive power by controlling the firing angle of the inverter.

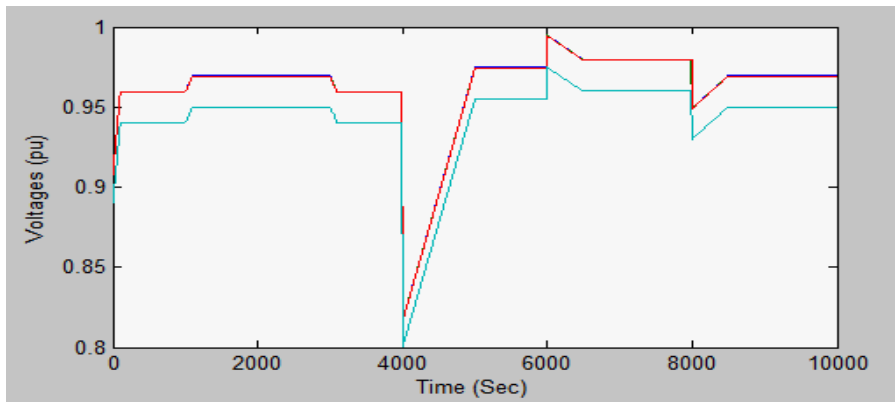

Fig.8: Voltage profile of the system with both solar \& wind penetration.

\section{Conclusion And Future Work}

Distributed generation is expected to play a major role in the electric power production of the future. Most likely,wind, PV, fuel cells and micro turbines will be the dominant grid-connected distributed generators (DGs). Impact of RES penetration on voltage stability in a micro grid is analyzed in this paper. Voltage variation occurs due to reactive power mismatch of the system. Voltage decrease with wind penetration and increase with solar penetration. This analysis shows that the effect of wind and solar penetration is different in nature, i.e., voltage profile considering both wind and solar type generation is better than the case where individual generation is considered once at a time. In faulted condition, the penetration of RES in both grid connected and islanded mode will effect adversely whether same type of renewable energy or renewable energy mixed is used. Besides, this adverse impact is more noticeable in islanded mode. Opportunities for future work abound in this research area. Improvement in forecasting accuracy alone can greatly help the imbalance reserve requirements. Possibilities for future study include the investigation of the impact of adding other renewable generation sources such as tidal power to the mix, as well as a study to determine the optimal combination of the various renewable resources to improve reserve requirements even further.

\section{References}

[1]. A. Canova, L. Giaccone, F. Spertino, and M. Tartaglia, "Electrical impact of photovoltaic plant in distributed network," IEEE Transactions on Industry Applications, vol. 45, no. 1, pp. 341-347, Jan.-Feb. 2009.

[2]. C. H. Lin,W. L. Hsieh, C. S. Chen, C. T. Hsu, T. T. Ku, and C. T. Tsai, "Financial analysis of a large-scale photovoltaic system and its impact on distribution feeders," IEEE Transactions on Industry Applications, vol. 47, no. 4, pp. 1884-1891, July-Aug. 2011.

[3]. J. Enslin, "Network impacts of high penetration of photovoltaic solar power systems," in IEEE Power and Energy Society General Meeting, July 2010, pp. 1-5. 
[4]. S. Bose, Y. Liu, K. BaheiEldin, J. de Bedout, and M. Adamiak, "Tieline controls in microgrid applications," in IREP Symposium on Bulk Power System Dynamics and Control - VII. Revitalizing Operational Reliability, Aug. 2007, pp. 1-9.

[5]. A. Anwar and H. Pota, "Loss reduction of power distribution network using optimum size and location of distributed generation," in $21^{\text {st }}$ Australasian Universities Power Engineering Conference (AUPEC), Sept. 2011, pp. 1-6.

[6]. N. Roy, M. Mahmud, and H. Pota, "Impact of high wind penetration on the voltage profile of distribution systems," in North American Power Symposium (NAPS), Aug. 2011, pp. 1-6.

[7]. A. Kumar and W. Gao, "Voltage profile improvement and line loss reduction with distributed generation in deregulated electricity markets," in TENCON, IEEE Region 10 Conference, Nov. 2008, pp. 1-6.

[8]. W. Deng, W. Pei, and Z. Qi, "Impact and improvement of distributed generation on voltage quality in micro-grid," in Third International Conference on Electric Utility Deregulation and Restructuring and Power Technologies, April 2008, pp. 1737-1741.

[9]. X. Zhang, H. Zhang, J. Guerrero, and X. Ma, "Reactive power compensation for parallel inverters without control interconnections in microgrid," in Industrial Electronics, IECON, 34th Annual Conference of IEEE, Nov. 2008, pp. 922-925.

[10]. Z. Ke, W. Jiang, Z. Lv, A. Luo, and Z. Kang, "A micro-grid reactive voltage collaborative control system configuring dstatcom," in Second International Conference on Mechanic Automation and Control Engineering (MACE), July 2011, pp. 1887-1890.

[11]. C. L. Anderson and J. Cardell, "Analysis of wind penetration and network reliability through montecarlo simulation," in Simulation Conference (WSC), Dec. 2009, pp. 1503-1510.

[12]. M. Shahabi, M. Haghifam, M. Mohamadian, and S. Nabavi-Niaki, "Microgrid dynamic performance improvement using a doubly fed induction wind generator," IEEE Transactions on Energy Conversion, vol. 24, no. 1, pp. 137-145, March 2009.

[13]. N. Maisonneuve and G. Gross, "A production simulation tool for systems with integrated wind energy resources," IEEE Transactions on Power Systems, vol. 26, no. 4, pp. 2285-2292, Nov. 2011.

[14]. J. Kabouris and F. Kanellos, "Impacts of large-scale wind penetration on designing and operation of electric power systems," IEEE Transactions on Sustainable Energy, vol. 1, no. 2, pp. 107-114, July 2010.

[15]. B. Klockl and P. Pinson, "Effects of increasing wind power penetration on the physical operation of large electricity market systems," in CIGRE/IEEE PES Joint Symposium on Integration of Wide-Scale Renewable Resources Into the Power Delivery System, July 2009, pp. 1-6.

[16]. K. N. Rashad M. Kamel, AymenChaouachi, "Effect of wind generation system rating on transient dynamic performance of the micro-grid during islanding mode," Scientific Research, Low Carbon Economy, vol. 1, pp. 29-38, Sept. 2010.

[17]. J. Kabouris and C. Vournas, "Designing controls to increase wind power penetration in weakly connected areas of the hellenic interconnected system," in IEEE Power Engineering Society General Meeting, July 2003, pp. 1964-1969

[18]. K. Nigim and W. J. Lee, "Micro grid integration opportunities and challenges," in IEEE Power Engineering Society General Meeting, June 2007, pp. 1-6.

[19]. L. Wang and C. Singh, "Pso-based multi-criteria economic dispatch considering wind power penetration subject to dispatcher's attitude," in 38th North American Power Symposium, Sept. 2006, pp. $269-276$.

[20]. A. Ciupuliga, M. Gibescu, E. Pelgrum, P. Jacobs, K. Jansen, and W. Kling, "Round-the-year security analysis with large-scale wind power integration,” IEEE Transactions on Sustainable Energy, vol. 3, no. 1, pp. 85-93, Jan. 2012.

[21]. J. Liang, S. Grijalva, and R. Harley, "Increased wind revenue and system security by trading wind power in energy and regulation reserve markets," IEEE Transactions on Sustainable Energy, vol. 2, no. 3, pp. 340-347, July 2011.

[22]. J. Duval and B. Meyer, "Frequency behavior of grid with high penetration rate of wind generation," in PowerTech, IEEE Bucharest, July 2 2009, pp. 1-6.

[23]. P. Gardner, M. Tremblay, and D. Price, "Technical requirements for high-penetration wind : What system operators need, and what wind technology can deliver," in CIGRE/IEEE PES Joint Symposium ON Integration of Wide-Scale Renewable Resources Into the Power Delivery System, July 2009, pp. 1-11.

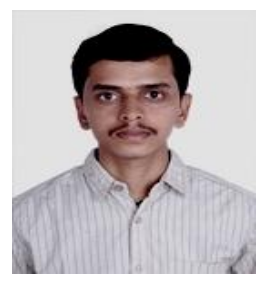

N.Ravi (M'2012) born in Hyderabad Andhra Pradesh in 1987 He received B.Tech in Electrical and Electronics Engineering from VNR VJIET , Bachupally Hyderabad in 2009. $\mathrm{He}$ worked in Bharat Dynamics Limited as Apprentice (Electrical Maintenance Engineering) in 2011-2012 as well as he worked in Battery Zone in Balapur, Hyderabad as Graduate Engineer in 2010-2011. He is currently working towards the M.Tech Degree in Electrical engineering in RVR \& JC Chowdhavaram, Guntur. His fields of interests are renewable energy, microgrid, power distribution system, distributed generator.

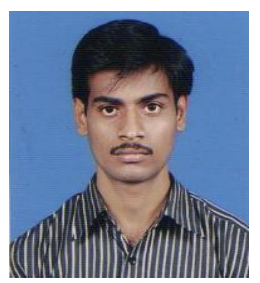

Y.Sumanth presently working as a Assistant Professor in R.V.R \& J.C College of Engineering, Guntur. He received his M.Tech degree from KLCE, in the year 2010.He received B.Tech degree from Nalanda Institute of Institute of Technology and Engineering, in the year 2008. His fields of interests are Renewable energy, microgrid and distributed generator, etc.

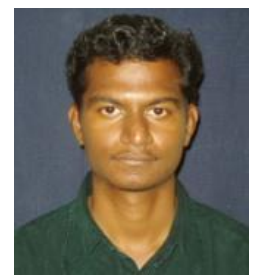

N.Dharani Kumar presently working as a Assistant Professor in, R.V.R. \&J.C College of Engineering, Guntur. He received his M.Tech degree from R.V.R \& J.C College of Engg. In the year 2010. He received B.Tech degree from Nalanda Institute of Technology and Engineering, in the year 2008. His fields of Interest are renewable energy, microgrid and renewable energy, microgrid and distributed generator etc. 